\title{
Anatomy of Nasal Cavity and Paranasal Sinuses; Surgical Perspective
}

\author{
Seung-Kyu Chung \\ Department of Otorhinolaryngology-Head and Neck Surgery, Samsung Medical Center, Sungkyunkwan University School of Medicine, \\ Seoul, Korea
}

술자 입장에서 바라본 비강 및 부비동 내시경 해부

정승규

성균관대학교 의과대학 삼성서울병원 이비인후과학교실

\author{
Received April 27,2020 \\ Revised May 16, 2020 \\ Accepted May 20, 2020 \\ Address for correspondence \\ Seung-Kyu Chung, MD, PhD \\ Department of Otorhinolaryngology- \\ Head and Neck Surgery, \\ Samsung Medical Center, \\ Sungkyunkwan University \\ School of Medicine, \\ 81 Irwon-ro, Gangnam-gu, \\ Seoul 06351, Korea \\ Tel +82-2-3410-3572 \\ Fax +82-2-3410-3879 \\ E-mail rhinochung@gmail.com
}

Endoscopic sinus surgery is a treatment method for chronic rhinosinusitis not controlled with medical treatment. It had started with functional endoscopic sinus surgery and the concept of reboot approach was introduced recently. For safe surgical treatment, understanding the anatomy especially personal variations between well-known structures is important. The practical points of surgical concept during endoscopic sinus surgery was suggested.

Korean J Otorhinolaryngol-Head Neck Surg 2020;63(5):189-98

Key Words Anatomy · Nasal surgical procedures · Paranasal sinuses.
내시경부비동 수술은 접근하는 방법에 따라 비내 또는 비 외 접근이 가능하고 수술 범위에 따라 부비동 내 국한되는 경우와 부비동을 통하여 주변 장기까지 접근하는 경우도 있 다. 수술을 하는 경우 안전하게 수술 목표를 달성하는 것이 중요하고 이를 위하여는 비강 및 부비동의 해부를 잘 알고 있 어야 한다. 비강과 부비동의 모양은 사람마다 차이가 있지만 개개 구조는 특성에 따라 이름이 붙여진 경우가 많다. 따라서 이름도 중요하지만 발생 기전에 따른 차이 및 주변 구조와의 상대적인 관계를 파악하는 것이 매우 중요하다. 맨눈으로 수 술하는 경우, 현미경을 사용하는 경우, 그리고 내시경을 사용 하는 경우에 따라 보이는 것이 달라지므로 상대적 관계를 파 악하는 것이 중요하다. 부비동의 해부 및 개개 구조에 대한

This is an Open Access article distributed under the terms of the Creative Commons Attribution Non-Commercial License (https://creativecommons.org/licenses/by-nc/4.0) which permits unrestricted non-commercial use, distribution, and reproduction in any medium, provided the original work is properly cited.
내용은 한글 교과서에 잘 기술되어 있으며,2) 해부학 용어는 매우 오래전부터 사용된 많은 용어의 정의가 확실하지 않고 명확한 구조를 지칭하지 못한 경우가 많이 있어 통일된 단어 를 사용하자는 의견들이 많이 나오고 있다. ${ }^{3-5)}$

\section{함기화에 대하여}

부비동이란 이름 그대로 비강에서 주변 뼈로 함기화가 된 것이며, 함기화가 진행하는 뼈에 따라 일정한 경향이 있다. 개 개 구조에는 여러가지 변형이 있으므로 이런 다양한 모양을 이해하기 위해 부비동이 발생하는 과정을 생각해야 한다. ${ }^{5)}$

사골내부로 복잡한 함기화가 진행하여 사골동이 되는데 구조가 매우 복잡하여 사골 미로라고 불리기도 한다. 사골동 의 내측은 중비갑개, 상비갑개의 갑개 부분에 의하여 비강과, 
외측은 지판으로 안구와, 상부는 사골동천정으로 뇌와, 그리 고 후방은 접형동과 접해 있으며, 하방에는 상악동이 있고 전 방에는 누낭(lacrimal sac)과 비루관(nasolacrimal duct), 그 리고 구상돌기(uncinated process)가 내측 하방을 구성하는 6면체로 생각할 수 있으며 상악동, 접형동은 이 6면체에 붙어 있고 전두동은 함기화가 사골동의 외측 전상부의 전두골까 지 연장된 것으로 생각하면 주변 해부학 이해에 도움이 된다.

6면체 모양의 사골동은 중비갑개의 기판을 경계로 전방에 있는 중비도를 통하여 함기화가 된 부분이 전사골동이 되고 후방의 상비도나 최상비도를 통하여 함기화가 되어 후사골 동이 된다. 하지만 수술 중 관찰하면 중비갑개의 기판에 구멍 이 있어 전사골동과 후사골동이 연결되어 있는 경우도 있다.

사골동은 사골에 있는 몇 개의 기판 사이로 그리고 기판내 로 함기화가 진행하여 발생한 공간이 되어 연결 구멍이 아닌
통로로 되어 있다(Fig. 1). 상악동은 중비도에서, 접형동의 경 우는 비강에서 한 개의 연결통로를 통하여 함기화가 진행하 고, 전두동의 경우는 전사골동에서 전두골 방향으로 진행된 함기화 중에 전방의 가장 큰 부분이라고 생각할 수도 있다.

사골내에는 몇 개의 기판이 존재하는데 6개가 존재한다고 쓰여 있기도 하지만 임상적으로는 1번이 구상돌기, 2 번이 사 골포(ethmoid bulla) 기판, 3번이 중비갑개 기판, 4번이 상비 갑개 기판, 그리고 최상비갑개의 기판이 존재한다고 생각한 다. 이러한 기판들 사이, 즉 사골누두(벌집뼈깔때기, ethmoidal infundibulum), 사골포 후방의 공간처럼 기판사이로 진행 하거나, 갑개 봉소(conchal cell)처럼 기판내로 진행되는 경우 도 있다. 사골내에서 함기화가 많이 진행하여도 위치가 변하 지 않는 구조로는 안구가 대표적이고 그 외에도 전후 사골동 맥, 접형동 주변의 시신경, 내경동맥, 상악동 상부의 하안와신

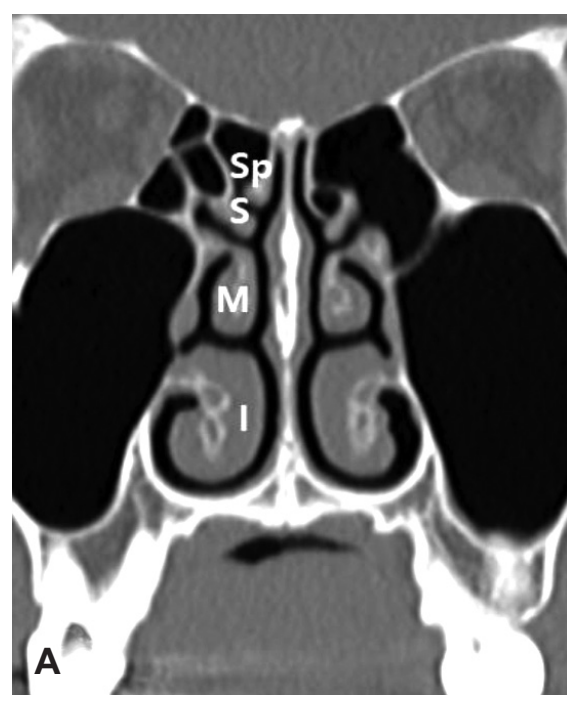

Fig. 1. The inferior $(\mathrm{I})$, middle $(\mathrm{M})$, superior $(\mathrm{S})$ and supreme turbinate $(\mathrm{Sp})$ are visible in one coronal image $(\mathrm{A})$. The uncinate process (UP), ethmoid bulla (B), middle turbinate, superior turbinate and supreme turbinate were seen in axial view $(B, C)$. The space $\left(^{*}\right)$ behind the ethmoid bulla is connected to superior meatus and located in posterior ethmoid sinus. MS: maxillary sinus.
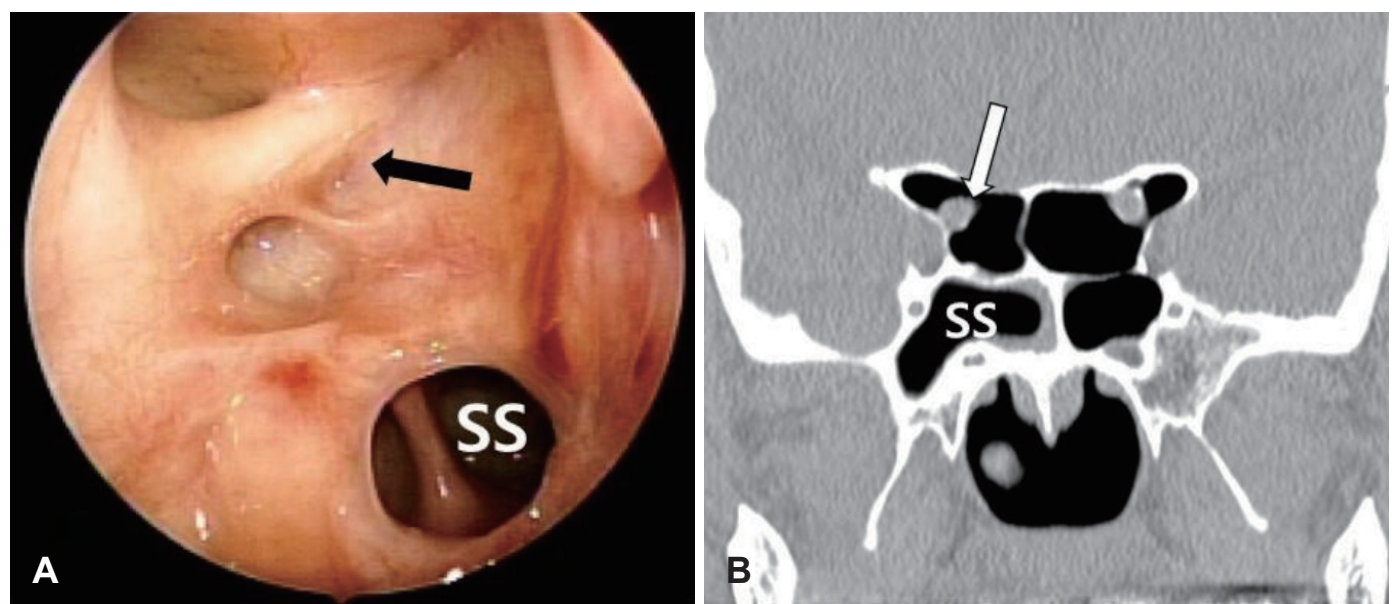

Fig. 2. Post-op endoscopic finding of optic canal (black arrow) in right Onodi cell (A). Surgical opening of sphenoid sinus (SS) is also seen. Pre-op coronal CT finding showing optic canal (white arrow) in Onodi cell (B). 


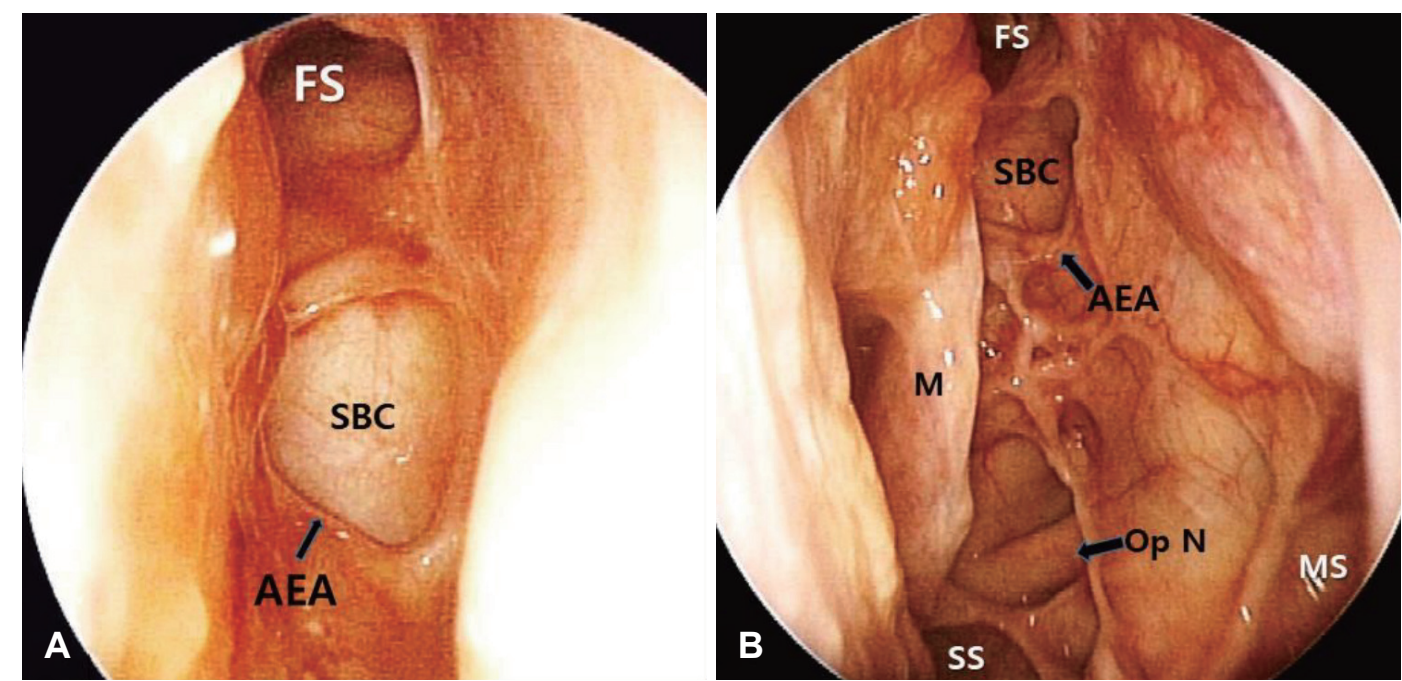

Fig. 3. Post-op endoscopic finding showing the right-side roof of anterior ethmoid sinus (A). Pneumatization to the frontal bone, anterior to the anterior ethmoid canal (AEA, arrow) is divided with frontal sinus (FS) and suprabullar cell (SBC). Post-op endoscopic finding of left ethmoid roof (B). From posterior to the anterior direction, sphenoid sinus (SS), optic nerve (Op N, arrow) in Onodi cell, suprabullar cell $(\mathrm{SBC})$ and frontal sinus (FS) are seen. MS: maxillary sinus, M: middle turbinate.

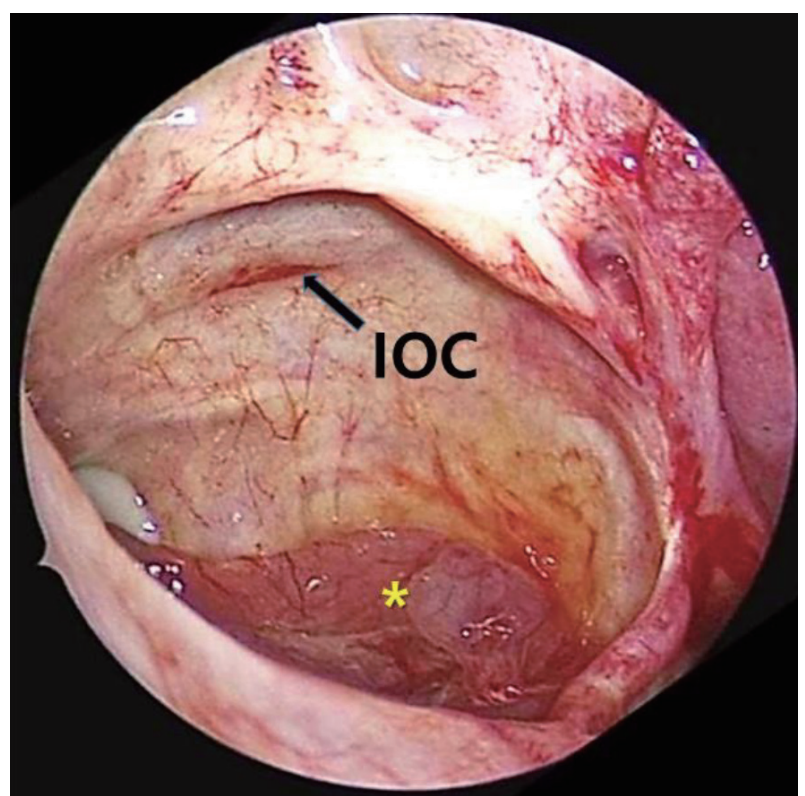

Fig. 4. Post-op endoscopic finding of widely opened right maxillary sinus with 30 degree endoscope. Infraorbital canal (IOC, allow) is seen in the upper wall of sinus. Mucosal edema $\left(^{*}\right)$ is noted in the inferolateral area.

경 등이 있다(Figs. 2-4). 수술할 때 이런 원칙에 따라 해당 환 자의 함기화 정도에 따른 해부학적 모습을 생각하면 도움이 될 것으로 생각한다.

사골을 벗어나 주변으로 함기화가 되는 extramural extension의 경우도 있는데 대표적인 것이 후방 경계인 접형동 내 로 진행하는 접형사골봉소(sphenoethmoid cell, Onodi cell) 가 있고 안구아래 상악동으로 진행하는 하안와 봉소(infraorbital cell, Haller cell) 등이 있다. 하안와 봉소와 중비갑개 봉소의 경우는 함기화가 전사골동에서 시작하기도 하고 후
사골동에서 시작하기도 한다. 가장 변화가 심한 부분은 사골 의 전상방외측의 전두골로 진행되는 함기화로 전두동 연결부 주변으로 기판들이 서로 붙었다 떨어졌다 하면서 공간의 변 화가 아주 심한 부분이다. 따라서 몇 개의 함기화가 어디에서 시작해서 어떤 3차원적 모습으로 진행하는 지를 생각하고 함 기화가 진행한 경계부를 알고, 많이 진행되는 경우 어떤 구조 가 관찰될지를 예측하는 것이 필요하다.

환자마다 부비동이 어떤 형태를 보이는지 알기 위하여는 $\mathrm{CT}$ 영상을 보고 판단해야 하는데 수술을 해야 하는 부위에 염증이 있으면 구조를 정확하게 구별하기 어려운 경우가 종 종 있다. 일반적으로 영상의 두께가 2 3 mm 정도 되는데 부 비동내 미세한 구조의 변화를 보여주기에 어려운 경우가 있 어 $1 \mathrm{~mm}$ 이내의 영상을 순차적으로 보면서 3차원적 모습을 상상하는 과정이 필요하다. 영상을 보는 프로그램에 따라서 축면(axial)영상, 관상(coronal)영상 그리고 시상(sagittal)영 상까지 동시에 보여주는 경우도 있어 같이 비교하면서 보면 더 이해하기 편하다. 축면영상의 경우 전방부가 영상의 상부 에 보이게 관찰하는 경우가 일반적이지만 영상에서 보이는 부분에 따라서는 아래 위를 바꾸어 전방부가 하방을 향하게 해서 보는 것이 수술의 방향과 더 일치한다고 생각되는 경우 도 있어 개인별로 확인해 보는 것도 권장한다.

술자의 입장에서는 다양한 함기화에 의하여 생기는 변이의 종류와 빈도를 고려하여 ${ }^{6)}$ 수술을 받는 사람의 해부학적 구 조가 다양한 변이 중에 어떤 모양인지를 파악하는 것이 중요 하다. 


\section{부위별 수술 해부}

부비동에 접근하는 방법은 술자마다 다른 방법을 권장하 기도 하지만 접근하는 부위의 해부를 잘 파악하는 것이 중요 하다. ${ }^{7-10)}$ 전비공를 통하여 내시경과 수술 기구를 넣고 비강내 좁은 부분 공간에서 수술이 진행되기 때문에 기구 및 내시경 의 진행 방향과 주변을 잘 구별해야 한다.

\section{사골동 하부로 진입하기}

내시경을 이용하여 부비동으로 들어갈 때는 중비도내 사 골동의 내측 하방을 통하여 접근하게 된다. 중비도 입구에서 만나는 구조는 외측벽에 비루관이 튀어나온 돌출 부위가 관 찰되는데 통일된 해부학적 명칭은 없지만 maxillary line 또 는 눈물능선(lacrimal bulge) 등으로 표현된다. ${ }^{11)}$ 이 구조를 지나 중비갑개의 전방외측 사이로 진입하여 구상돌기를 만나 게 된다. 구상돌기의 형태에 따라 다르겠지만 정상적인 경우 는 구상돌기의 자유연과 중비갑개 사이로 사골포의 부분이 보이기도 한다. 우선 구상돌기의 내측 자유연 부분를 제거하 여 시야를 확보해야 하는데 이때 가장 중요한 점이 주변에 있 는 구조를 다치지 않고 구상돌기를 안전하게 제거하는 것이 다. 따라서 구상돌기가 외측 전방의 상악골의 전두돌기나 누 골에 붙는 부위를 잘 파악해야 한다. 경계를 파악하기 위하 여 이곳의 점막을 수축시키면 비루관에 의하여 튀어나온 돌 출부의 후방으로 약간 들어갔다 튀어나오는 홈이 보인다 (Fig. 5). 이곳이 구상돌기가 붙는 곳이고 이 붙는 부위의 후 방으로 구상돌기의 두께보다 조금 더 기구를 삽입하여 사골
누두까지만 진입하는 것이 중요하다. 사골누두의 후벽이 사 골포의 전벽이 되는데 그 외측에 안구가 존재한다. 따라서 정확하게 누두까지 기구를 삽입하는 감각이 중요하다. 또 다 른 방법은 구상돌기의 자유연이나 붙는 부분을 기구로 흔들 어 움직임을 관찰하여 붙는 부분을 확인하기도 한다.

붙는 자리 내부의 골부는 일부분만 붙어 있어 점막만 있고 골부가 없는 부분도 있다. 내시경으로 구상돌기를 제거하는 것은 부착 부위에서 떼어주는 것이다. 따라서 사골누두의 앞 부분을 제거하는 것은 어렵지 않지만 하비갑개와 붙으면서 일부는 상악동 천문부(fontanelle)로 이동하는 부위, 즉 상악 동의 자연구가 열리는 부분은 해부학적 구조가 복잡하다. 따 라서 누골(lacrimal bone)에 손상을 주지 않도록 제거하는 것이 중요하다. 자연구 주변 수술을 할 때 주의해야 할 점은 자연구의 전방부의 골부를 제거할 때 비루관이 손상될 수 있다는 점이다. 자연구의 후방을 제거할 때 기구로 밀게 되면 상악동의 상후방에 붙어 있던 점막이 떨어져 나올 수 있어 주변에 힘이 전달되지 않도록 절제하는 것이 중요한데 이 때 사용 가능한 기구, 즉 환자의 점막과 같은 방향으로 작동하 는 기구를 찾는 것이 쉽지 않다.

전방 내측 하방으로 구상돌기를 제거하고 들어가면 사골 포의 전벽이 보이고 이 전벽의 내측에서 외측으로 제거하면 외측 지양판에 붙는 부분은 수직으로 붙는다. 사골포는 사 골기판과 중비갑개 기판사이로 진행되는 함기화가 사골포기 판을 앞으로 밀면서 생기므로 앞에서 보면 마치 둥글게 튀어 나온 모습으로 보이게 된다. 사골포의 내측은 중비갑개의 외 측 벽과 연결이 되지는 않고, 후방은 후사골포 함요(retrobu-
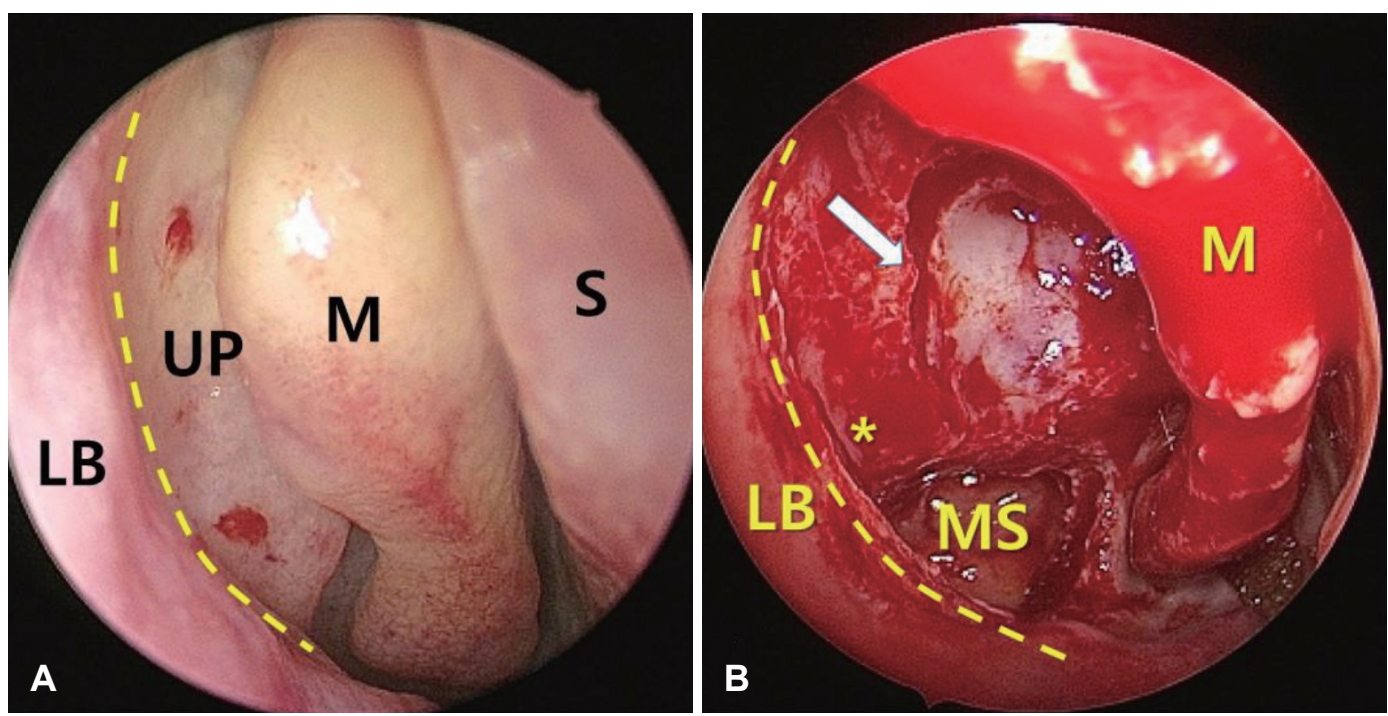

Fig. 5. Endoscopic finding of lateral nasal wall anterior to the middle turbinate (M) of right nasal cavity (A). The bulge of lacrimal structure (LB) is noted just anterior to the attachment potion (yellow dotted line) of the uncinated process (UP). Finding after removal of uncinated process, anterior wall of ethmoid bulla and partial removal of middle turbinate (B). The opened Infundibulum ( $\left.{ }^{*}\right)$ is noted between cutting edges of uncinated process and cutting margin of anterior wall of ethmoid bulla (white arrow). The inside of the maxillary sinus (MS) is also noted. 

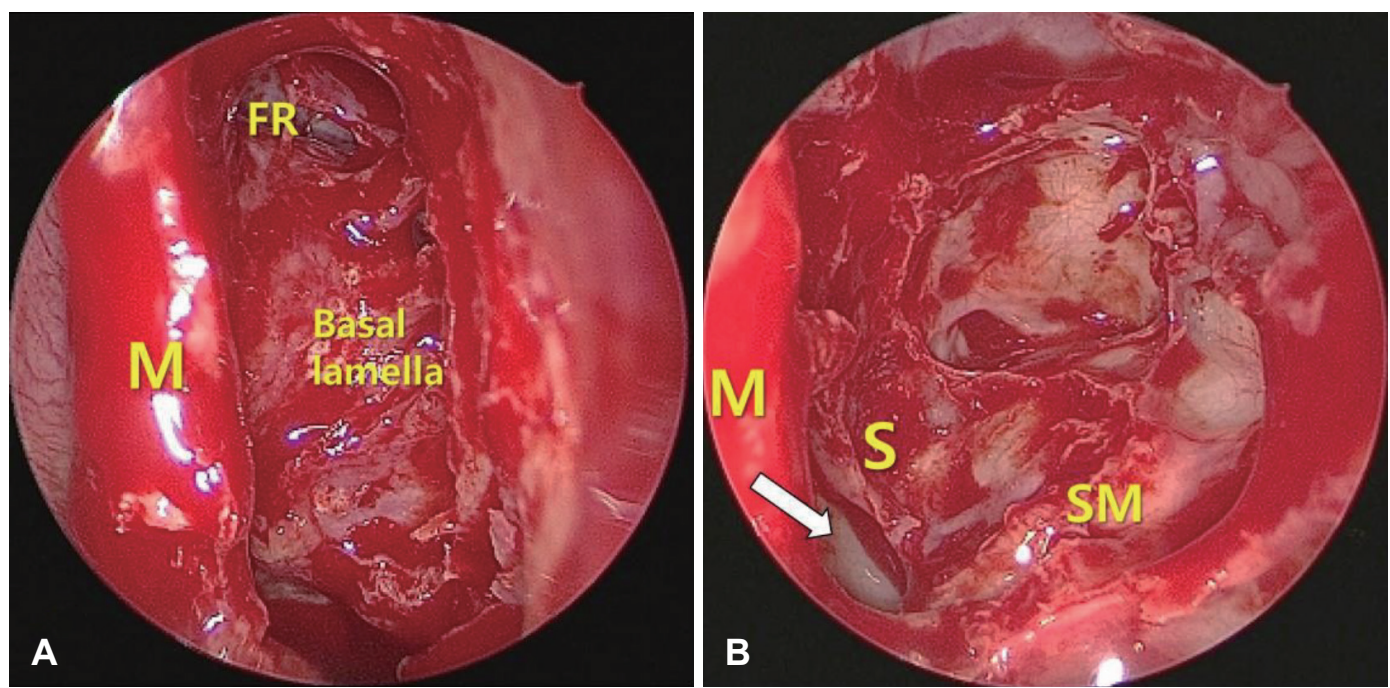

Fig. 6. Endoscopic finding of the basal lamella of middle turbinate which is the posterior wall of anterior ethmoid sinus after removal of uncinate process and ethmoid bulla (A). Frontal recess (FR) is seen at the anterior portion. The anterior portion of the middle turbinate $(\mathrm{M})$ is removed partially. Endoscopic finding of posterior ethmoid sinus after removal of the basal lamella of middle turbinate (B). The anterior inferior part of superior turbinate (S) was removed and septal mucosa (arrow) is seen through the superior meatus (SM).

lar recess), 상부는 상사골포 함요(suprabullar recess)가 된 다. 사골포가 제거되면 중비갑개의 기판이 보이게 된다. 사골 포의 후벽이 있는 경우 중비갑개의 기판과 분리되어 별도의 격벽으로 존재하기도 하고, 기판과 합쳐져 하나의 격벽으로 존재하기도 한다. 기판을 제거할 때는 하방과 외측의 안전한 부분을 제거하게 된다. ${ }^{12)}$

\section{후사골동 진입}

중비갑개의 기판을 통과하여 후사골동으로 진입하게 되며 이때 전사골동의 내측 경계부의 모습을 잘 파악해야 한다. 특히 중비갑개의 기판이 후외측으로 진행하는 경우 내측 경 계를 모르고 진행하면 안와로 들어갈 수 있다. 따라서 비강에 서 중비갑개, 상비갑개의 방향을 확인하고 사골동의 내측으 로 진행해야 한다. 중비갑개의 기저판이 후외측으로 향하면 서 2 개의 판으로 갈라지는 경우가 대부분인데 2 개의 기판 사 이로의 함기화는 주로 상비도에서 오게 된다.

중비갑개의 기판이 외측으로 방향을 바꾸는 것이 보이거 나 비강의 진행방향에 따라 제거하여 상비도와 연결이 되면 이 부분을 내측으로 제거하여 상비갑개의 전방을 관찰되고 그곳에서 내측으로 보이는 부분은 비중격이 되어 비강에서 상비도가 시작되는 부분을 확인한 것이 된다(Fig. 6). 이 때 상비갑개의 내측 하방을 제거하여 접형사골함요(sphenoethmoidal recess)를 확인하고 비중격과의 사이에 존재하는 접형동의 개구부를 확인하게 된다. 접형동 개구부의 위치에 따라 다르기는 하지만 비내 접근시 중비갑개의 후방기저부가 남아 있으면 기구 접근이 어려운 경우가 있다.

상비도에는 상비도 전벽과 상비도 후벽이 있고 전벽은 중

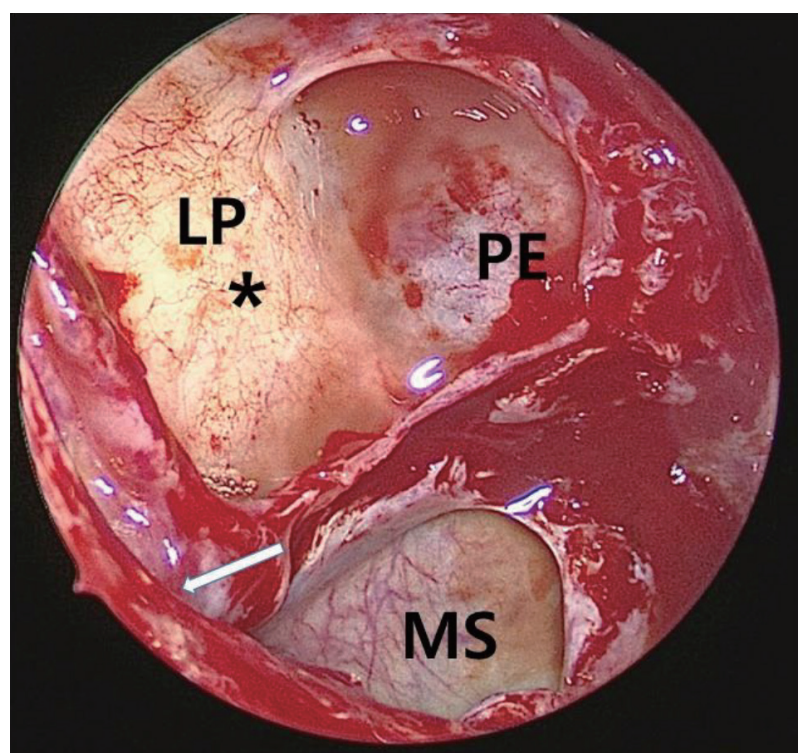

Fig. 7. Endoscopic finding of right ethmoid sinus after removal of the uncinated process, anterior wall of ethmoid bulla and widening of fontanelle. The mucosa in the lateral wall of ethmoid sinus $\left(^{*}\right)$ looks white compare to the bone septa. Arrow depicts the exposed infundibulum. LP: lamina, PE: posterior ethmoid sinus, MS: maxillary sinus.

비갑개의 후방 기판이, 후벽은 상비갑개의 전방 기판이 된다. 상비갑개는 2 개의 기판으로 이루어지며 이 기판의 사이로 함 기화가 되면 최상비도가 된다.

후사골동의 기판은 상비갑개, 최상비갑개에서 후상방외측 으로 진행하므로 기판의 후방에 있는 공간을 확인하고 기판 의 방향을 따라 제거하게 된다. 사골동의 벽면은 기판에 비 하여 점막이 백색으로 보이는 경우가 많다(Fig. 7). 6면체의 후상방경계는 접형동과의 경계인데 사골동에서 진행된 함기 
화의 정도에 따라 두 부비동 사이의 경계판의 위치와 방향이 달라지는데 하방은 일정하고 상방이 접형동으로 진행하는 경 향이 있다. 후사골동이 접형동으로 함기화가 진행한 경우를 접형사골봉소라고 부른다. ${ }^{13)}$ 이때 중요한 것은 사골동 6 면체 의 후면 외측 상방에 일정하게 존재하는 구조가 시신경인데 신경 주변으로 진행된 함기화의 정도에 따라 보이는 모습이 달라지게 된다(Figs. 2 and 3B).

\section{접형동 접근}

접형동으로 접근하는 방법에는 비강과 연결된 개구부를 통과하는 방법, 사골동과 접형동의 경계판을 통과하는 방법, 그리고 접형동의 전방 중앙부를 통과하는 방법 등이 있다. 개구부를 통해 접근하기 위하여는 개구부를 찾는 것이 중요 한데 위치가 비중격과 상비갑개의 후방 사이, 즉 접형사골함 요에 존재하는데 높이 및 외측으로 위치는 환자마다 다르므 로 CT를 보고 위치를 확인하여 예상부위로 Freer 거상기처 럼 끝이 부드러운 기구가 구멍이 열리는 방향으로 부드럽게 삽입되는 것을 확인하며 찾는 것이 중요하다. 개구부를 확장 하는 경우 내측 하방으로 넓히라고 쓰여있는 교과서도 있지 만 바로 밑으로 지나가는 접형구개동맥의 비중격분지에 손상 이 발생할 수 있으므로 하방으로 넓히는 경우는 점막을 보존 하고 골부만을 제거하는 것이 바람직하다. 다른 방법은 개구 부의 외측상부의 사골동과 접형동 사이 격벽을 제거하는 방 법으로 상비갑개가 접형골에 붙는 부분의 하부를 제거하여 접형동의 개구부를 확인하고 외측 상방으로 후사골동의 후 벽을 제거하는 방법이다. 후사골동의 후벽의 하방으로 격벽 을 제거하여 접형동 내로 접근한 뒤 격벽을 외측으로 제거하
는 방법을 사용하기도 한다. 이때 접형사골봉소가 있는 경우 그 함기화의 정도에 따라 사골동과 접형동 사이 격벽의 3차 원적 모습이 달라지므로 그 경사 정도를 파악하고 제거하는 것이 매우 중요하다(Fig. 3). 이 격벽의 외측 상방으로 시신경 과 내경동맥이 존재하므로 격벽만 제거하는 것이 필요하다.

\section{사골동 후방에서 앞으로}

수술 시 후방에서 앞으로 진행하면서 관찰하면 육면체의 외측이 안구를 따라 함기화가 진행되는데, 함기화가 상방으 로 많이 진행될수록 상부에서 잘 보이는 구조가 전사골동맥, 후사골동맥이 지나가는 관이 된다(Fig. 3). 특히 전사골관의 경우는 해당 부위에 중비갑개 기판이 부착되어 전후 사골동 이 나눠지는 경계 부위가 된다. 사골동 상부의 함기화가 전사 골관의 전후로 진행되면 전사골관이 마치 천장에 매달려 있 는 듯한 모습을 보이기도 한다. 전사골관의 후방에서는 안구 를 따라서 외측 상방으로 진행되는 함기화가 없으나 전사골 관의 전방부에서는 일반적으로 안구의 상방을 따라 외측 상 방으로, 즉 전두골부로 함기화가 진행하며 경우에 따라서는 전사골관의 상방으로 안구를 따라 후사골동의 상부로 함기 화가 진행되기도 한다(Fig. 8). 후사골동 하부의 외측으로의 함기화는 안구 밑으로 진행하며 경우에 따라 외측 하방에서 전방으로 진행하여 상악동의 외측 상부로 함기화가 되기도 한다.

\section{전사골동의 외측 상부에서 전두동까지}

사골동 6면체의 전방부, 즉 전사골동 부분은 안구를 따라 외측 상방으로 함기화가 진행되는데 이 부분은 전두골을 따
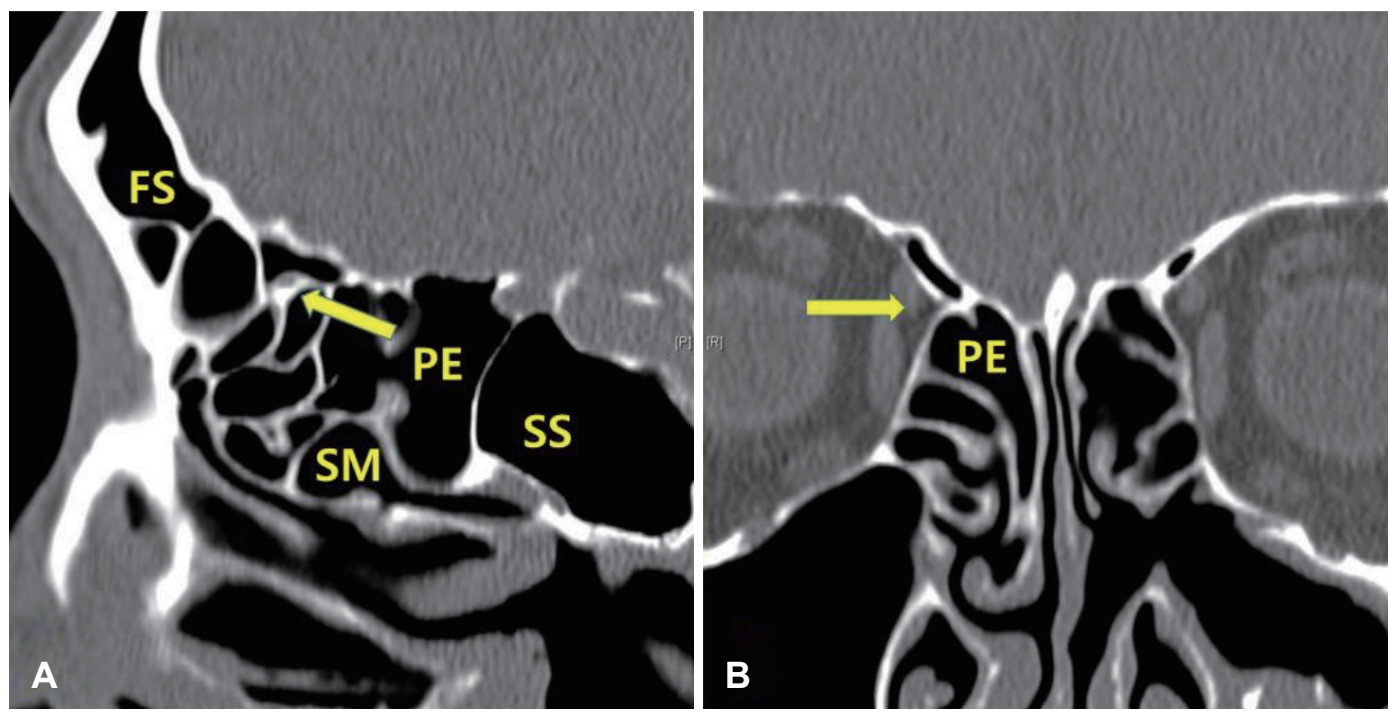

Fig. 8. Anterior ethmoid artery (arrow) is seen in sagittal (A) and coronal (B) CT images. Pneumatization is processed posteriorly over the anterior ethmoid canal. FS: frontal sinus, SM: superior meatus, PE: posterior ethmoid sinus, SS: sphenoid sinus. 
라 진행된다. 이 부분의 모양은 너무 다양하여 개개 구조에 대한 기준 및 용어가 매우 다양하다.,14-16) 전방에 전두골의 일부가 후방으로 튀어나온 부분이 frontal beak가 되며 이 부분이 전방에서 병목처럼 작용할 때도 있다.

전두동은 전사골동 부위에서 전두동으로 진행하는 여러 개의 함기화 중에 가장 전두골과 경계가 되는 부분으로 주로 내측 전방에서 진행되는 함기화에 의하여 연결 통로가 존재 하게 된다. 이 연결 통로는 모래시계 모양으로 전두동에서 좁 아지는 부분이 frontal infundibulum, 중간에 가장 좁은 부 분이 전사골동의 연결구가 되고 그후로 넓어지면서 사골동 에 연결되는 부분을 전두와(frontal recess)라고 칭한다. 이 이론에 의하면 전두와의 위치는 매우 변화가 많아 보인다. 일 반적으로 전방에 있는 봉소의 내측이며 후방에 존재하는 봉 소의 앞에 있다고 알려져 있다. 열리는 위치는 사람마다 다 르므로 그 개인의 경우를 영상에서 파악하는 것이 필요하다.

전두동의 하방에 존재하는 봉소에 대하여 frontal cell type I-IV로 나눠서 기술한 논문도 있고 ${ }^{15)}$ frontoethmoid cell로 기술하며 장소에 따라 전방에 존재하는 봉소로는 비제봉소 (agger cell, aggger nasi), supra agger cell, supra agger frontal cell, 내측에 존재하는 봉소로는 intersinus septal cell(frontal septal cell), 그리고 후방에는 상사골포봉소(supra bulla cell), supra bulla frontal cell, 상안와봉소(supraorbital ethmoid cell) 등을 기술하였다.3,4) 이 부분은 매우 다
양한 변화를 보이고 있고 구상돌기 및 사골포의 기판이 상 부로 올라가면서 부위에 따라 없어지기도 하고 다시 생기는 경우도 있어 명확히 말하기는 어렵지만 사골포의 상부 함기 화의 전방이 전두동의 후벽이 되는 것은 거의 일정해 보인다.

구상돌기의 상부가 부착 부위에 따라 3 가지로 나누는 방 법이 있는데 3차원적 구조를 관상영상의 한 단면으로 판단 하는 것은 부정확해 보인다. 그보다는 전방에 존재하는 비제 봉소의 후벽을 확인하고 frontal beak 하방의 외측와 내측까 지 구별하고 그 상방은 함기화 모습에 따라 제거하는데 이때 중요한 것은 좌우의 경계를 확인하여 주변 장기로 들어가지 않는 것이 필요하다.

따라서 전두동의 경우는 전두동 하방의 격벽을 모두 제거 하면 될 것으로 판단되지만 이 경우 수술에서 주의해야 할 점은 격벽이 제거된 수술 후 모습을 상상하면서(Fig. 3) 주변 장기와의 경계부를 손상하지 않도록 경계부를 잘 판단하는 것이다.

\section{상악동으로의 접근}

상악동은 상악동 내로 상악동 자연구를 통하여 함기화가 진행된 공간이고 자연구는 중비도의 앞부분에 있는 사골누 두의 전하방에 존재한다. 천문(fontanelle)은 자연구에서 후 방으로 중비도와 상악동 사이에 존재하는 양면이 점막으로 된 부분인데 그 안으로 구상돌기 또는 하비갑개 등과 연결된
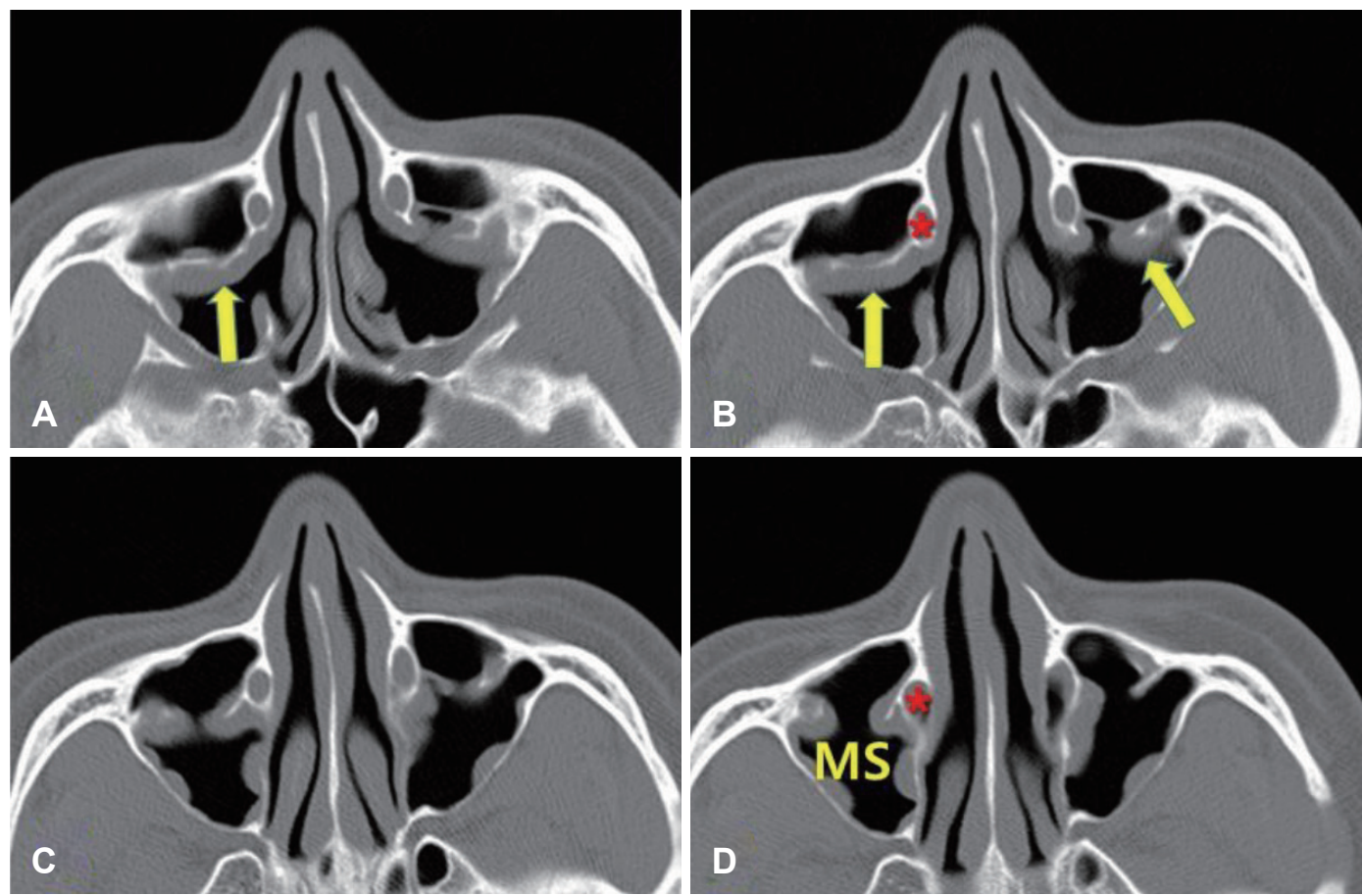

Fig. 9. The bony septa (arrow) connecting lacrimal canal $\left(^{*}\right)$ and inferior orbital nerve canal is seen in the upper portion of both maxillary sinuses (MS). The images showing inferior portion from $A$ to $D$. 
골조직이 있을 수 있다. 상악동에는 구상돌기에 의하여 나눠 지는 전천문과 후천문이 있다고 하는데 임상적으로 천문 내 부로 구상돌기의 후방부분이 존재하므로 나눠진 이름으로 생각된다. 수술시는 가장 전방에 존재하는 연결부를 자연구 로 생각하고 seeker를 사골누두의 외측 벽을 따라 이동시킬 때 처음 상악동으로 들어가는 느낌을 받는 곳이라 생각하면 된다. 흔치는 않지만 전방에 있는 구상돌기의 하방, 후방 외 측에 존재하는 사골포 또는 하안와봉소에 함기화가 많이 되 어 있으면 자연구가 원형의 구멍이 아닌 공간처럼 보이는 경 우도 있다. 자연구 후방의 천문 부분을 절제겸자로 제거한다. 상악동 상부에 전방으로 진행하는 튀어나온 구조는 하안와 신경이며(Fig. 4) 종종 상악동 전상방에 칸막이처럼 생긴 골
판이 있을 수 있다(Fig. 9). ${ }^{17)}$ 상악동의 함기화 정도에 따라 다 르지만 상악동의 전방, 하방내측으로 함기화가 많이 되어 있 으면 $30^{\circ}$ 내시경의 시야로 잘 안 보여 $70^{\circ}$ 이상의 내시경을 사 용할 필요가 있다.

하안와부위와 중비갑개로의 함기화

안구의 상부로 진행되는 함기화는 전사골관의 전방에서 진행되나 안와 아래로 진행되는 함기화는 다양한 모양을 나 타낸다. 사골포의 외측 또는 전방에 있는 경우를 Haller cell 이라고 지칭하였으나 사골포의 전방, 후방 또는 외측에 존재 하기도 하므로 하안와 봉소로 부르는 것이 좋아 보인다(Fig. 10). ${ }^{18,19)}$ 함기화가 시작되는 부위는 상악동, 사골누두, 중비도

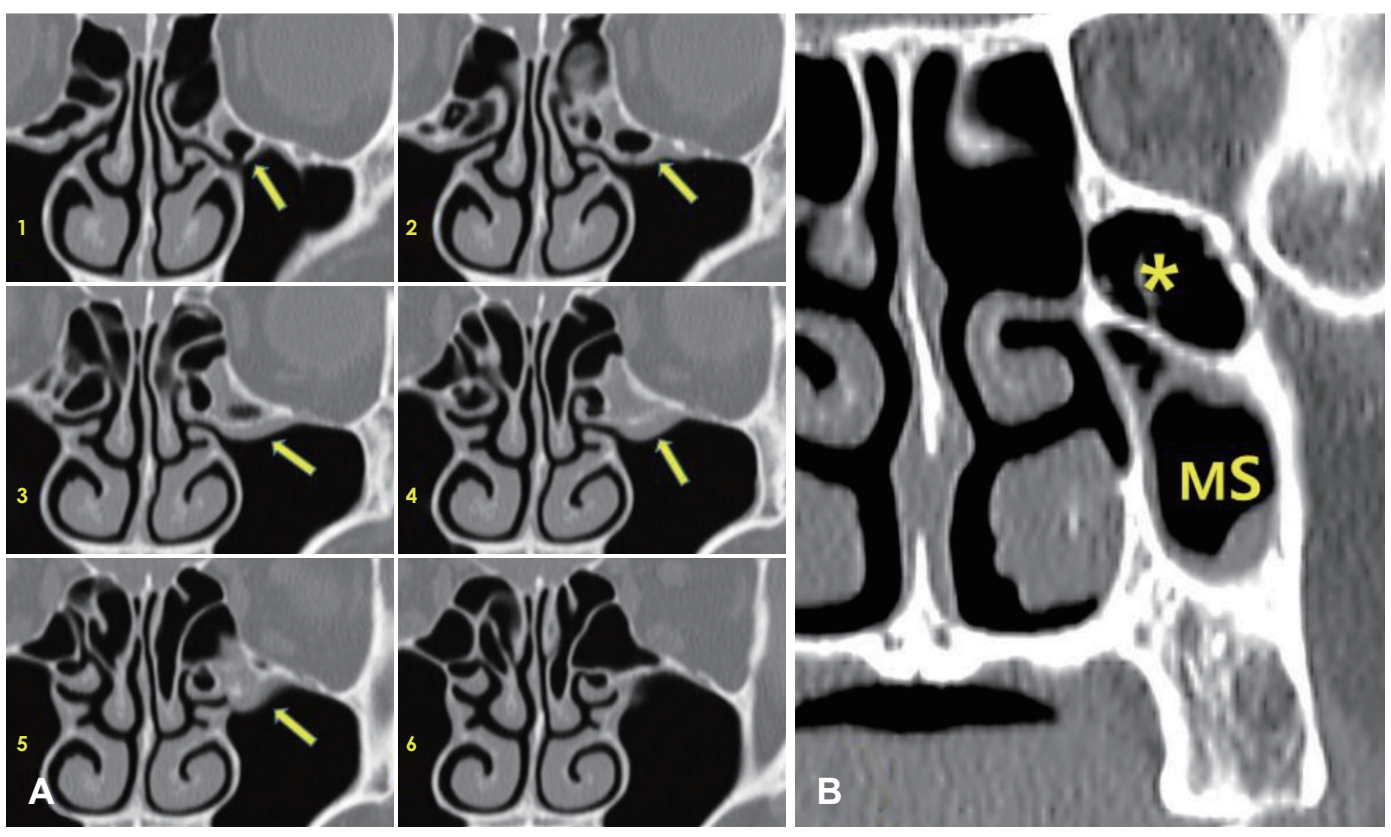

Fig. 10. Serial coronary images showing infraorbital cell (arrow) (A). The opening of the cell is noted in the middle meatus in image 1 and the cell is filled with secretion partially. The posterior margin of this cell is noted in image 5 . Another case of infraorbital cell $\left({ }^{*}\right)$ pneumatized from superior meatus over the maxillary sinus (MS) (B).
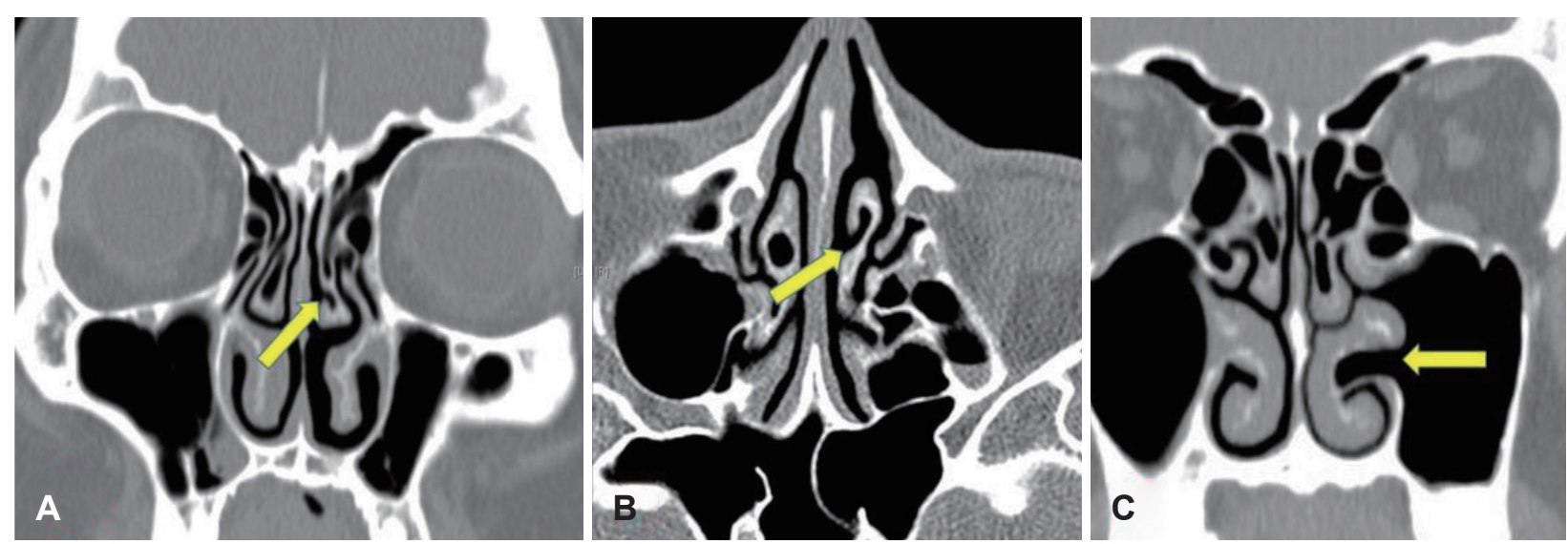

Fig. 11. Conchal cells are noted bilaterally. Pneumatization to the left conchal cell (arrow) is started from nasal cavity (A, B). Pneumatization to the inferior tirbinate (arrow) from the maxillary sinus in noted in coronal CT image (C). 


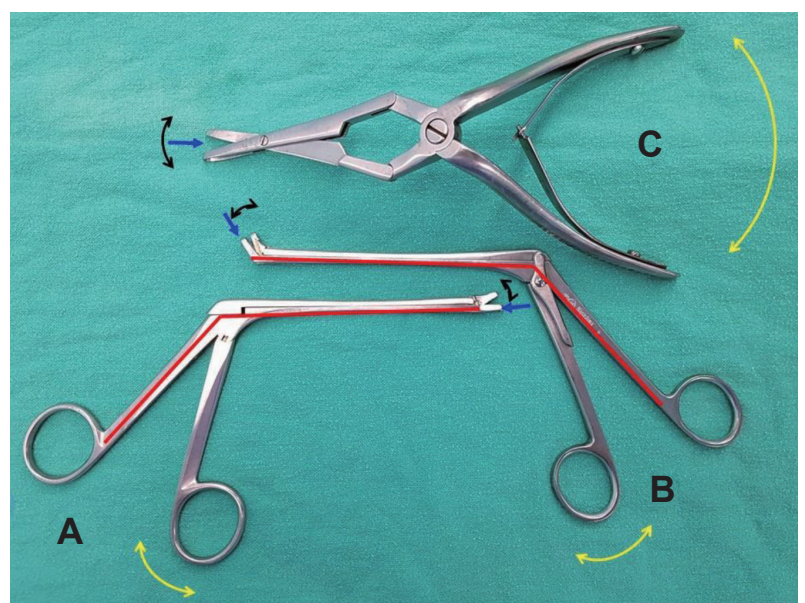

Fig. 12. The movement pattern of surgical instruments. In the Grunwald cutting fcorceps (A, B), fixed portion is depicted with red line. Fixed portion and mobile portion are present in the cutting portion and handles. The range of movement in the cutting portion is depicted with black curved lines with tip in both side and that in the handle is depicted with yellow curved line with tip in both side. The blue arrow depicts the planes of cutting area. In the Jansen Middleton septum forceps (C), the cutting portion and handles move simultaneously. The plane of cutting area is the center line of instrument.

의 후방 등 전사골동에 있을 수도 있고 후사골동의 상비도 의 외측에서 전방으로 진행하기도 한다. 따라서 이 부분을 열 어주기 위하여는 함기화가 시작되는 부위를 확인하는 것이 필요하다. 후사골동에서 외측으로 안구 하방으로 함기화가 진행되는 경우는 전방 경계가 되는 중비갑개의 외측 부위를 제거하여 내부를 관찰할 정도까지 만드는 경우도 있다.

중비갑개로 함기화가 진행되는 경우가 있는데 기판내로 진 행되는 갑개봉소의 모습을 보이는 경우와 interlamellar cell 의 형태를 보이는 경우가 있다. 갑개봉소의 형태를 보이는 경 우는 함기화가 시작되는 부위가 중비도인 경우가 많고 interlamellar cell의 모습을 보이는 경우는 후사골동의 상비도 에서 함기화가 진행하게 된다. 경우에 따라 여러 곳에 함기화 가 되기도 하며 아주 드물게는 비강에서 함기화가 진행되는 경우도 있다(Fig. 11). 상비갑개에도 다양한 함기화가 진행될 수 있다. ${ }^{20)}$

\section{수술시 제거 범위와 안전한 기구 사용}

함기화가 한 개의 골판을 사이에 두고 진행하는 경우 두 부분을 안전하게 연결하는 것은 이 판을 제거할 때 남는 골 벽에 있는 점막은 남기고 제거하는 방법이다. 점막이 종종 두 꺼워져 있으며 골부와 약하게 붙어 있어 쉽게 골부에서 떨어 지기도 한다. 점막을 보존하기 위하여 절제겸자를 사용하는 데 기구의 절단면과 제거하고자 하는 부분이 평행 되어야 한 다(Fig. 12). 일반적으로 절단기구의 절개부에 고정부가 있는 경우는 이 고정부의 면에 절단부위를 맞추어야 한다. 따라서
고정부가 저항없이 삽입되는 공간까지, 즉 골부제거 시 외측 벽을 손상하지 않는 범위를 확인하고 기구절개부의 고정부가 움직임 없이 자를 수 있도록 절제하고자 하는 부위에 붙이 고, 기구의 고정부가 움직이지 않도록 기구에 따라 다른 손 잡이 부위의 특성에 따라 손가락을 적절히 사용하여 절제하 도록 해야 한다. 사용하는 기구에 따라 절제 면의 각도가 다 르므로 가장 잘 맞는 기구를 선정해야 한다. 사골동 내 기판 의 외측부분은 지판에 수직에 가깝게 붙으므로 제거시 절단 면이 이 방향에 맞는 기구를 사용해야 한다.

기능부비동내시경수술의 경우는 부비동이나 봉소가 비강 과 연결되는 부분을 확대해주는 것을 목적으로 하므로 상악 동과 접형동 이외에 사골동내 붕소, 그리고 전두동의 연결부 를 정확하게 판단하고 수술 후 연결부의 입체적인 모양을 생 각하고 시술하는 것이 권장된다.

\section{Acknowledgments}

None.

\section{ORCID}

Seung-Kyu Chung https://orcid.org/0000-0001-6187-0980

\section{REFERENCES}

1) Kim KS, Kim GB. Nasal anatomy. In Kim KS, editor. Clinical Rhinology. Gyeonggi-do: Koonja Publishing Company;2017. p.1-33.

2) Lee JG, Bae JH. Development and anatomy of nose and paranasal sinus. In Kim JS, editor. Otorhinolaryngology-Head and Neck Surgery, Rhinology. Gyeonggi-do: Koonja Publishing Company;2018. p.1-27.

3) Lund VJ, Stammberger H, Fokkens WJ, Beale T, Bernal-Sprekelsen $\mathrm{M}$, Eloy $\mathrm{P}$, et al. European position paper on the anatomical terminology of the internal nose and paranasal sinuses. Rhinol Suppl 2014;24:1-34.

4) Wormald PJ, Hoseman W, Callejas C, Weber RK, Kennedy DW, Citardi MJ, et al. The International Frontal Sinus Anatomy Classification (IFAC) and Classification of the Extent of Endoscopic Frontal Sinus Surgery (EFSS). Int Forum Allergy Rhinol 2016; 6(7):677-96.

5) Márquez S, Tessema B, Clement PA, Schaefer SD. Development of the ethmoid sinus and extramural migration: The anatomical basis of this paranasal sinus. Anat Rec (Hoboken) 2008;291(11):1535-53.

6) Vaid S, Vaid N. Normal anatomy and anatomic variants of the paranasal sinuses on computed tomography. Neuroimaging Clin $\mathrm{N}$ Am 2015;25(4):527-48.

7) Amine MA, Anand V. Anatomy and complications: Safe sinus. Otolaryngol Clin North Am 2015;48(5):739-48.

8) Dalgorf DM, Harvey RJ. Chapter 1: Sinonasal anatomy and function. Am J Rhinol Allergy 2013;27 Suppl 1:S3-6.

9) Ramakrishnan Y, Zammit-Maempel I, Jones NS, Carrie S. Paranasal sinus computed tomography anatomy: A surgeon's perspective. J Laryngol Otol 2011;125(11):1141-7.

10) Ogle OE, Weinstock RJ, Friedman E. Surgical anatomy of the nasal cavity and paranasal sinuses. Oral Maxillofac Surg Clin North Am 2012;24(2):155-66, vii.

11) Chastain JB, Cooper MH, Sindwani R. The maxillary line: Anatomic characterization and clinical utility of an important surgical landmark. Laryngoscope 2005;115(6):990-2.

12) Ferreli F, Mercante G, De Virgilio A, Cugini G, Pirola F, Gaino F, et 
al. "L" shape technique for endoscopic sinus surgery: An alternative method. Am J Otolaryngol 2020;102471.

13) Meybodi AT, Vigo V, Benet A. The onodi cell: An anatomic illustration. World Neurosurg 2017;103:950.e5-6.

14) Tran LV, Ngo NH, Psaltis AJ. A radiological study assessing the prevalence of frontal recess cells and the most common frontal sinus drainage pathways. Am J Rhinol Allergy 2019;33(3):323-30.

15) Bent JP, Cuilty-Siller C, Kuhn KA. The frontal cell as a cause of frontal sinus obstruction. Am J Rhinol 1994;8:185-92.

16) McLaughlin RB Jr, Rehl RM, Lanza DC. Clinically relevant frontal sinus anatomy and physiology. Otolaryngol Clin North Am 2001;34(1):1-22.

17) Whyte A, Boeddinghaus R. The maxillary sinus: Physiology, development and imaging anatomy. Dentomaxillofac Radiol 2019; 48(8):20190205.

18) Caversaccio M, Boschung U, Mudry A. Historical review of Haller's cells. Ann Anat 2011;193(3):185-90.

19) Herzallah IR, Saati FA, Marglani OA, Simsim RF. Retromaxillary pneumatization of posterior ethmoid air cells: Novel description and surgical implications. Otolaryngol Head Neck Surg 2016;155(2): 340-6.

20) Kajiwara R, Omura K, Takeda T, Ohira S, Matsuura K, Furuya H, et al. Anatomical variation of the pneumatized superior turbinate and its impact on endoscopic sinus surgery in chronic rhinosinusitis. Surg Radiol Anat 2020;42(1):81-6.

\section{정답 및 해설}

답 (5)

해 설 Esthesioneuroblastoma(olfactory neuroblastoma)에 대한 설명이다.

(1) 일반적으로 방사선 치료에 반응이 좋다.

(2) 경부 임파선 전이는 $20 \sim 25 \%$ 의 환자에서 존재한다.

(3) Adenoid cystic carcinoma에 대한 설명이다.

(4) SCC에 대한 설명이다.

참고 문헌: Cummings Otolaryngology: Head and Neck Surgey 6th edition, Amsterdam: Elsevier Health Sciences;

2014. p.1177-8. 